\title{
SUMMARY OF OCCURRENCE AND TAXONOMY OF SILICIFIED AGATHOXYLON-TYPE OF WOOD IN LATE PALEOZOIC BASINS OF THE CZECH REPUBLIC
}

\author{
Václav Mencl ${ }^{1,2 *}$, Jan Burešs ${ }^{3}$ Jakub Sakala ${ }^{2}$
}

${ }^{1}$ Municipal Museum Nová Paka, F.F. Procházky 70, 50901 Nová Paka, Czech Republic; mencl@muzeum.cz
${ }^{2}$ Charles University in Prague, Faculty of Science, Albertov 6, 12843 Praha 2, Czech Republic; rade@natur.cuni.cz
${ }^{3}$ Palaeontology Department, West Bohemian Museum in Pilsen, Kopeckého sady 2, 30100 Plzeň, Czech Republic;
rallus@seznam.cz
* Corresponding author

\begin{abstract}
The late Paleozoic deposits in several basins in the Czech Republic are well known for their abundance of silicified stems. Despite the fact they have been known since 19th century, there are few modern works of this material. The stems have been known to occur at several stratigraphic levels. During the course of recent field work such material has been found at additional levels. Most of them belong to the genus Agathoxylon, divided here into two types: cordaitalean plants and conifers. Based on previous data from Intra Sudetic and Pilsen Basins, and new material from Krkonoše Piedmont and Kladno-Rakouník Basins, this work compiles and compares the occurrence, anatomical features and taxonomy of silicified Agathoxylon-type of stems through four studied areas. The various cordaitalean - conifer ratio among all basins reflect different palaeoenvironment in each of them.
\end{abstract}

Key words: silicified wood, stem anatomy, Agathoxylon-type of wood, cordaitaleans, conifers, late Paleozoic, Czech Republic.

\section{INTRODUCTION}

Silicified araucarioid wood is an important element of the floras from the late Paleozoic Czech basins. There are several papers which recently described this type of wood from different parts of the Bohemian Massif (e.g., Matysová, 2006; Mencl, 2007; Mencl et al., 2009; Holeček, 2011; Bureš, 2011, 2013; Opluštil et al., 2013).

The nomenclature of araucarioid wood has been often discussed, and several various names have been applied to this wood over time (e.g., Dadoxylon Endlicher, Agathoxylon Hartig, Araucarioxylon Kraus, and Dammaroxylon J. Schultze-Motel). Present palaeoxylologists generally prefer the use of term Agathoxylon for such wood (Rößler et al., in press) and we follow this usage herein.

\section{HISTORICAL INSIGHT}

\subsection{Krkonoše Piedmont Basin}

Silicified plant remains in area of Nová Paka (Figure 1) have been known for many years. Their occurrence was first mentioned, as far as we can ascertain, by Maloch (1844) (see Heber, 1844) who described stems in the villages of Pecka and Stupná. Goeppert (1858) presented the first scientific description of the conifer wood Araucarites schrollianus (= „Dadoxylon“ saxonicum; synonym: „Dadoxylon" schrollianum), as well as calamitalean wood and stems of ferns from Kozinec, Nová Paka and Pecka. Occurrences of Medullosa, Psaronius and Agathoxylon stems and the existence of silicified peats in Nová Paka and Lázně Bělohrad were described by Frič (1912). In his work, special attention was paid to insect borings on the stem surface, and to the presence of small axes of the climbing fern Ankyropteris brongniartii, occasionally preserved in the root mantle of Psaronius stems. Vysocký (1859), Jokély (1861), Stur (1877), Makowsky (1878), Katzer (1892), Daněk (1902), Petrascheck (1924) and Hynie (1927) reported on the silicified stems from around Nová Paka. In the Nová Paka region, stems are most often found as lag on hillsides as loose pieces, less commonly they 


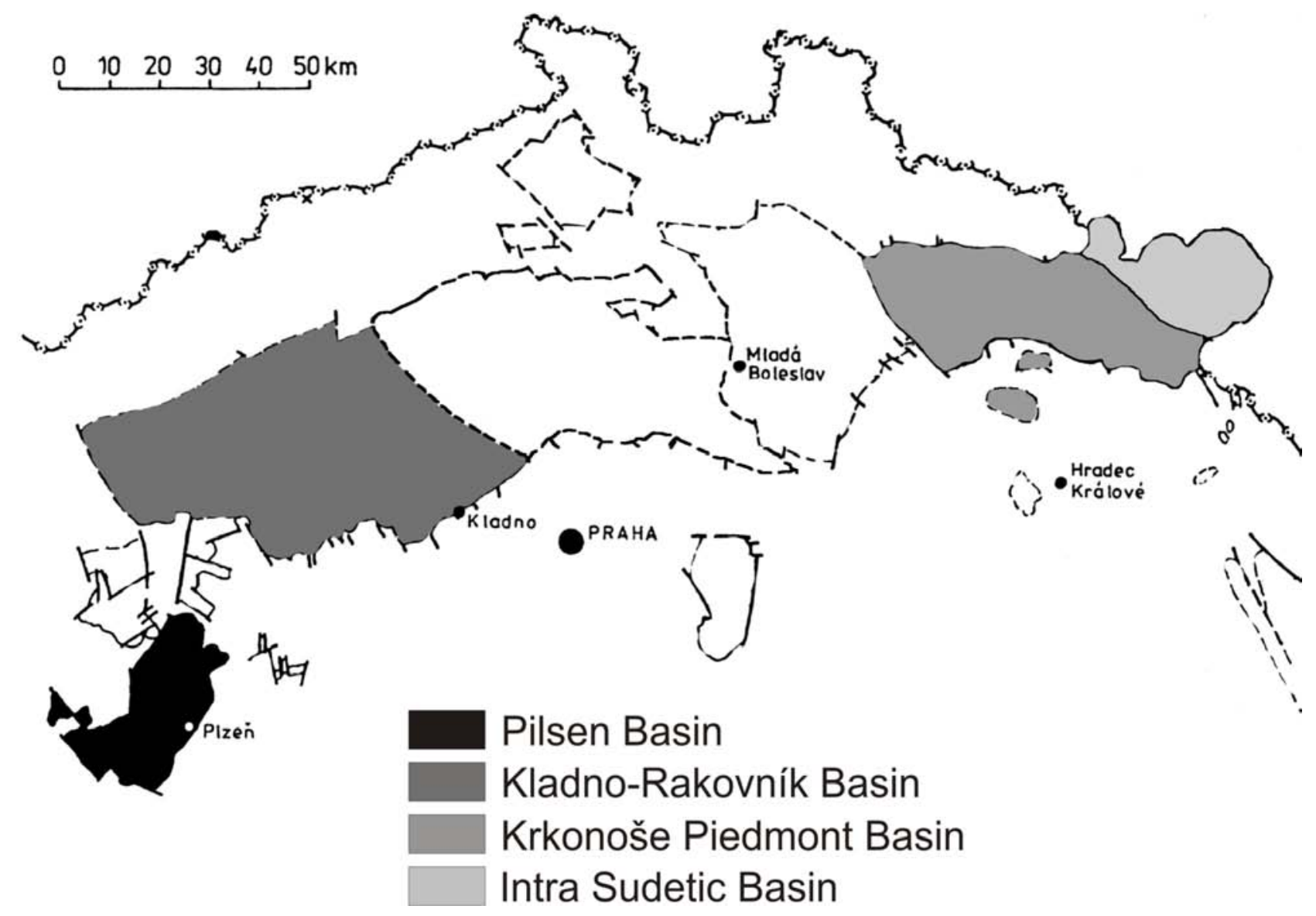

Figure 1. Late Paleozoic basins of the Czech Republic. Studied areas are highlighted. After Pešek et al. (2001).

have been found in outcrops, but never in upright position (Purkyně, 1927). Some specimens preserve bark and leaf scars (Renger, 1858, 1863). Feistmantel (1873a, b, c) generally considered silicified stems from the Nová Paka to be early Permian, but recent research indicates that they are of late Pennsylvanian (Kasimovian - Gzhelian) age (Pešek et al., 2001; Matysová, 2006; Mencl, 2007; Mencl et al., 2009; Mencl et al., 2013; Opluštil et al., 2013). The most recent general summary of silicified stem localities in Czech Republic was presented by Březinová (1970). Most recently short notes on the material from the Krkonoše Piedmont Basin have been published by Havlena (1955, 1958), Vítek (1986), Soukup (1997), Dernbach (1996) and Dernbach et al. (2002). Subsequent to Goeppert (1858) no detailed anatomical study of the Agathoxylon-type wood has been published.

\subsection{Intra Sudetic Basin}

In the Czech part of the Intra Sudetic Basin (Figure 1) silicified wood have been known for a long time. The first scientific descriptions were presented by Goeppert $(1857,1858)$ based on silicified wood in the Jestřebí hory region; an area about $30 \times 7.5$ kilometres.

The length of stems reaches up to $6 \mathrm{~m}$, and diameter varies between 40 and $50 \mathrm{~cm}$. Most are oval in cross-section due to compression. Some logs have preserved growth rings and knots with stubs of branches, and all lack bark (Goeppert, 1858). Systematically these fossils were interpreted as conifers and attributed to the species Araucarites brandlingii (Lindl. \& Hutt.) Göpp. and Araucarites schrollianus Göpp. (Goeppert, 1857, 1858).

Occurrences of silicified stems in the Intra Sudetic Basin mentioned also many other authors, 
e.g., Stur (1877), Makowsky (1878), Katzer (1892), Petrascheck (1924), Purkyně (1927), Březinová (1970) and Tásler et al. (1979). The most modern research was performed by Matysová (2006), Mencl (2007) and Mencl et al. (2009) who interpreted this material as cordaitalean wood.

\subsection{Kladno-Rakovník Basin and Pilsen Basin}

The occurrence of petrified stems in the KladnoRakovník and Pilsen Basins (Figure 1) has been known for about 150 years. Such fossil material is less common in this basin than in the Krkonoše Piedmont area. The first mention of such material in the Pilsen Basin was by Miksch (1853) who described stems up to $7.5 \mathrm{~m}$ in length from locality Chotíkov. The first anatomical studies of silicified stems were performed by Feistmantel (1873a, b, c), who described many stems from the Kladno-Rakovník Basin (localities Rakovník, Lubná, Hředle, Řevničov, Klobuky and Krušovice). He assigned different wood types to the conifer Araucarites schrollianus (= „Dadoxylon" saxonicum; synonym: „Dadoxylon“ schrollianum), and fern Psaronius (Feismantel, 1873b). These stems are without bark, some have growth rings, knots and pith cavities (Feistmantel, 1873c). First taxonomic description of silicified stems from both basins was provided by Feistmantel (1883). He determined one well-preserved piece of wood from Mutějovice (Kladno-Rakovník Basin) to belong to Araucarioxylon schrollianus, several loose-pieces from Lochotín as the cordaitalean wood Araucarioxylon brandlingi (Lindl. \& Hutt.) Göpp., and from Líně and Červený Újezd he identified wood as the conifer Araucarites schrollianus Göpp. (Feistmantel, 1883). Frič (1912) described silicified wood from a sandstone near Kněževes, and one stem uniquely preserved in outcrop of whitish sandstone near Klobuky. Purkyně (1927) provided a summary of petrified stems from Bohemia, including the new localities; Očihov, Kryry and Slaný; where black coloured silicified wood was found. He attempted stratigraphic correlations based on the occurrence of fossil wood (Purkyně, 1912). The possible applications of the silicified wood for stratigraphic correlations were also discussed by Němejc (1953), Pouba and Špinar (1954), and Pešek (1968). Subsequently Skoček (1970) divided petrified wood in two taphonomic types: dark which organic matter is present (deposited in swamps and partly humified), and light which lacks organic matter, which were deposited under dry climatic conditions (Skoček, 1970). Short notes about silicified stems were mentioned by several other authors, e.g., Němejc (1953), Pouba and Špinar (1954), Havlena (1964), Březinová (1970), Obrhel (1977), Řehoř and Řehoř (2005) and Svejkovský (2009). A short note about the silicified peat and fossil wood in the Kloubuky area was published by local collectors (Dvořák and Švancara, 2003). A palaeoichnological study was performed by Mikuláš and Zasadil (2008), who described silicified stems with insect boreholes and fungal traces from Kněževes, Hředle, Bílenec, Očihov a Stachov. The newest systematic work on silicified stems from the Kladno-Rakovník Basin summarised the occurrences of various types of stems and described their anatomy was done by Holeček (2011). Silicified conifer and cordaitalean stems from the Pilsen Basin and their anatomical features were described by Bureš (2011, 2013).

\section{GEOLOGICAL SETTINGS}

\subsection{Krkonoše Piedmont Basin}

The Krkonoše Piedmont Basin is situated in the northern part of the Czech Republic, at the foot of the Krkonoše-Jizerské hory crystalline complex (Figure 1) and belongs to a system of post-orogenic extensional/transtensional basins of the Bohemian Massif. Purely continental deposits in the Krkonoše Piedmont Basin are early Moscovian (Asturian) to early (or even middle) Triassic in age (Figure 2). The sediment fill of this basin reaches a maximum thickness about $1800 \mathrm{~m}$ (Pešek et al., 2001).

Previous geologic mapping indicates that silicified Agathoxylon-type stems are known from two stratigraphic levels: the Štikov Arkoses (Kumburk Formation) and the Ploužnice Horizon (Semily Formation) (Pešek et al., 2001). More recently this wood has been found in both the Brusnice Member (lower Kumburk Formation) and the lower Prosečné Formation. Stems, when found in place are horizontal on bedding planes; no upright stems have been observed. 


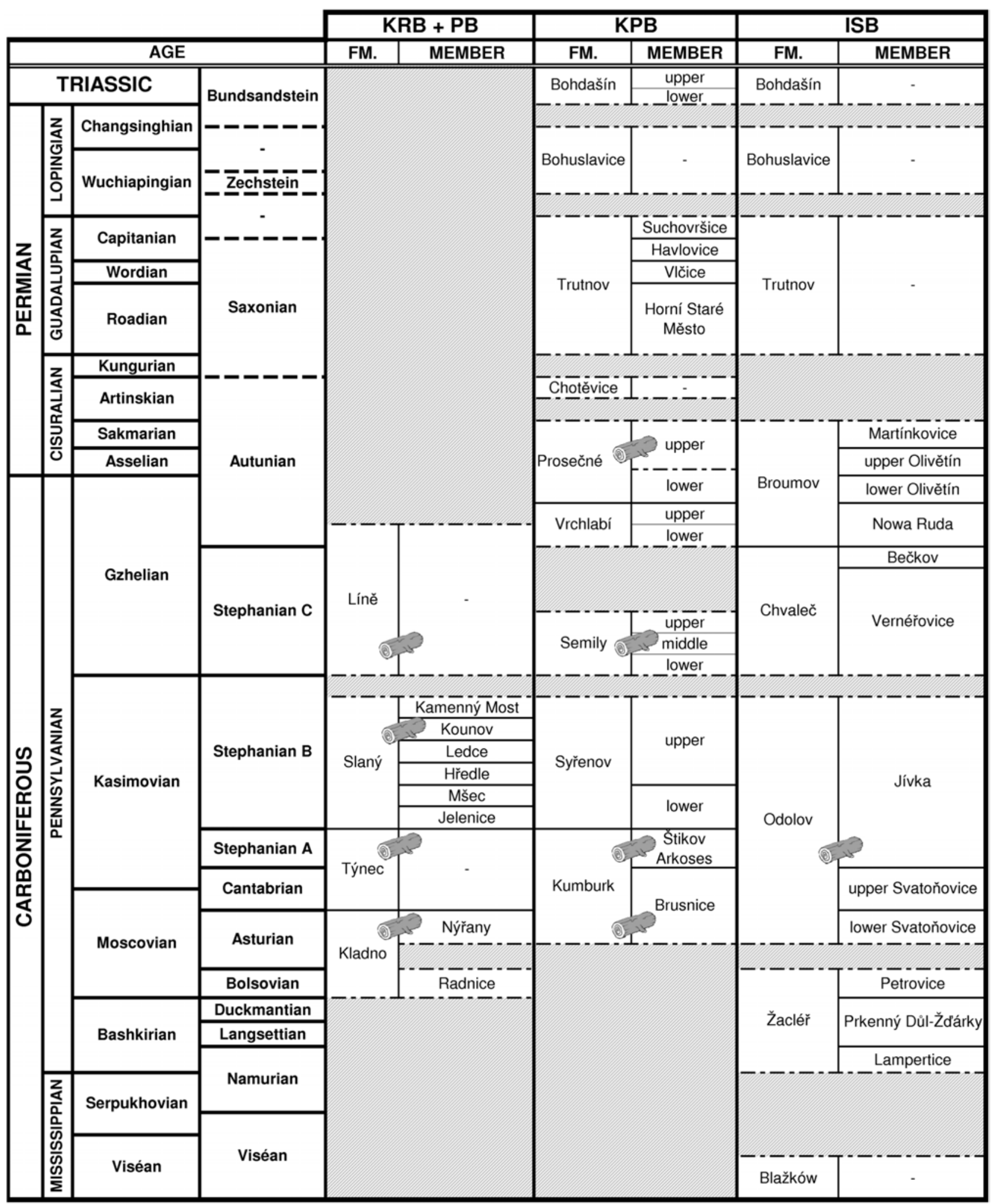

Figure 2. Comparison of stratigraphy of the Kladno - Rakovník Basin (KRB), Pilsen Basin (PB), Krkonoše Piedmont Basin (KPB) and Intra Sudetic Basin (ISB). Stratigraphical positions of the silicified stems are illustrated by small logs. Compiled after Mencl et al. (2009), Holeček (2011) and Gradstein et al. (2012). 


\subsubsection{Kumburk Formation}

Brusnice Member (lower Kumburk)

This unit is upper Moscovian - lower Kasimovian (Asturian - Cantabrian) in age. It consists mostly of reddish aleuropelites with common, several metre thick intercalations of greyish, middle- to coarse-grained, semi-rounded to rounded, siliciclastic conglomerates (Pešek et al., 2001). This unit is only known to occur in the southern part of the Krkonoše Piedmont Basin. It was deposited in lacustrine and fluvial environments with no volcanic component (Matysová et al., 2010). Silicified stems are rare and have not yet been described from this unit. A single silicified stem was observed in horizontal position in an outcrop of coarse-grained conglomerate by one of the present authors (V. Mencl).

\section{Štikov Arkoses (upper Kumburk)}

This unit is Kasimovian (Stephanian A) in age. Deposits are middle- to coarse-grained, light grey, reddish and pinkish sandstones that may laterally become conglomeratic with rounded cobbles up to 10 centimetres in diameter (Pešek et al., 2001), probably deposited in lacustrine and/or fluvial environment without any volcanic influence (according to Matysová et al., 2010). Silicified Agathoxylon stems are very abundant and often preserved in outcrops. The longest log, which has been ever found in this area, was more than 8 metres long and about 1 metre in diameter.

\subsubsection{Semily Formation}

Ploužnice Horizon (middle Semily)

This unit is Gzhelian (Stephanian C) in age. The sediments have a mostly lacustrine character (Pešek et al., 2001). They consist of fine-grained, reddish mudstones and siltstones with thin carbonate banks, calcareous and chert concretions. There is a volcanic component represented by intercalated tuffs and tuffitic sandstones which were deposited by traction mechanisms, mostly by river streams (Stárková et al., 2009). Silicified remnants of plants are, for the most part, restricted to the lower part of the Ploužnice Horizon. This unit has yielded Agathoxylon-type of wood, silicified stems of the fern Psaronius, the calamitaleans (Arthropitys and Calamitea), and the seed-fern (Medullosa) as well as nodules of carnelian (Sakala et al., 2009; Mencl et al., 2013; Opluštil et al., 2013). Due to the lack of outcrops, the silicified stems are usual- ly found as lag. This unit was deposited in a lacustrine environment with influence of volcanism (according to Matysová et al., 2010).

\subsubsection{Prosečné Formation}

The Prosečné Formation is Asselian - Sakmarian (Autunian) in age. It is only known from the central and western part of the Krkonoše Piedmont Basin. It is a very fine-grained lacustrine deposit with numerous interbedded tuffs, tuffites and limestones. The uppermost part of the Prosečné Formation is composed of pinkish arkoses and arkosic sandstones (Pešek et al., 2001). The usually darkcoloured silicified stems are very common in some localities, but found as lag only. This unit was deposited in a lacustrine environment with influence of volcanism (according to Matysová et al., 2010).

\subsection{Intra Sudetic Basin}

The Czech part of the Intra Sudetic Basin is in the north-eastern Czech Republic (Figure 1). Its sediments have the greatest stratigraphic range among the late Paleozoic basins of the Bohemian Massif, ranging from Viséan to the Middle Triassic (Pešek et al., 2001; Opluštil and Cleal, 2007; Opluštil et al., 2013) (Figure 2). Strata are divided into eight formations (Tásler et al., 1979; Pešek et al., 2001). The Intra Sudetic Basin is separated from the Krkonoše Piedmont Basin by the HronovPoříćí Fault. Sediments in the Intra Sudetic Basin are continental, with the exception of the Mississippian (Viséan) deposits that are partly marine. All other deposits have fluvial, proluvial or lacustrine character. A volcanoclastic component is present in several units (Pešek et al., 2001). Silicified wood is known only from one stratigraphic level called the Žaltman Arkoses in the Odolov Formation. The presence of silicified stems in the Petrovice Member (Bolsovian) that were mentioned by Tásler et al. (1979) was not confirmed (Mencl, 2007; Mencl et al., 2009). The Žaltman Arkoses is Stephanian A in age and composed of fluvial arkosic conglomerates and sandstones (Pešek et al., 2001, Valín, 1956, 1960). Stems are very rarely found in outcrops (e.g. Kryštofovy kameny), they are allochthonous and never found in upright position. They lack bark, roots, branches or any other extraxylary tissue (Mencl et al., 2009). Most are found as loose pieces in the field. They are most common in the area of the Jestrebí Hory (Matysová, 2006; Mencl, 2007; Mencl et al., 2009). 


\subsection{Kladno-Rakovník Basin and Pilsen Basin}

The Kladno-Rakovník and Pilsen Basins are situated in the central and south-western part of the Czech Republic (Figure 1). They were formed by an extension/transition during the Variscan orogeny in the Bohemian Massif. The oldest sediments are early Moscovian and the youngest are Gzhelian in age (Figure 2), with a maximum thickness about 1440 metres. These mostly lacustrine sediments are divided into four formations, i.e. the Kladno, Týnec, Slaný and Líně Formations. Silicified wood is known to occur in all formations (Holeček, 2011), but is most common in the Týnec and Líně Formations (Pešek et al., 2001). Exposures of these formations are extremely poor or lacking thus all fossil wood has been found as fragments in eluvium. Some however have been recovered from kaolin mines in the Pilsen Basin. Whole trunks are very rare, petrified wood is often fragmented into small pieces, knots and remnants of branches are very scarce.

\subsubsection{Kladno Formation}

The Kladno Formation is Moscovian (Bolsovian Cantabrian) in age and is composed of the Radnice and Nýřany members separated by a hiatus. Both are typified by dark-coloured, greyish and reddish fluvial deposits, mostly claystones, siltstones, sandstones and conglomerates in the Radnice Member, and arkoses, arkosic sandstones and siltstones in the Nýřany Member. Both units contain coal beds and common volcanic intercalations. The very scarce silicified stems in the Kladno Formation are mostly black in colour.

\subsubsection{Týnec Formation}

The Týnec Formation is lower Kasimovian (Barruelian) and is typified by coarse-grained reddish sediments, without or only with little volcanic intercalations. Petrified stems are very common in this unit and usually light-coloured. Trunks, up to $10 \mathrm{~m}$ long, have been described from this formation by Pešek et al. (2001). Two types of wood are present: Agathoxylon-type and calamitalean (Mencl et al., 2013).

\subsubsection{Slaný Formation}

Slaný Formation is Kasimovian (Stephanian B) in age, divided into six members that are composed of mostly grey-coloured sediments. Silicified stems, known only from the Kounov Member (upper part of the Slaný Formation, Fig. 2), are quite rare and usually dark-coloured. The Kounov Member is typified by fluvial and lacustrine deposits, mostly white to greyish arkoses, arkosic sandstones and aleuropelites with coal beds and tuffitic interbeds.

\subsubsection{Líně Formation}

The Líně Formation is Gzhelian (Stephanian C) in age and separated from the Slaný Formation by a hiatus. It consists primarily of reddish to crimsoncoloured silt and claystones. Tuffs and tuffites are more common than in the underlying Slaný Formation, and are can be distinguished within three units (horizons), i.e. the Zdětín, Klobuky and Stránka Horizons (Pešek et al., 2001). Silicified Agathoxylon-type stems are very common in arkosic deposits of the lower part of the Líně Formation. Stems are found there as loose pieces in the field, except one unique specimen, which was preserved in outcrop and described by Frič (1912). From this stratigraphic position were also described calamitalean stems (Mencl et al., 2013). In the Klobuky area, there are also known silicified peats (e.g., Dvořák and Švancara, 2003).

\section{MATERIAL AND METHODS}

The samples from the Krkonoše Piedmont Basin are either from the palaeontological collections of the Municipal Museum Nová Paka (signature P), the Krkonoše Museum in Jilemnice (abbreviation J), or were provided by V. Mencl and private collectors (abbreviations BA, C, HB, JA, PE, S, SH). The samples from the Kladno-Rakovník Basin were collected by J. Holeček and are now housed in the West Bohemian Museum in Pilsen (abbreviations RAK, ZAS), or provided by private collectors (abbreviation ZAJ). The samples from the Pilsen Basin were provided by the West Bohemian Museum in Pilsen (signature FP), or came from the collection of the Municipal Museum Nová Paka (signature $\mathrm{P}$ ).

Cross sections of several tens of specimens were polished and examined in reflected light with a Leica EZ 5 and Olympus SZx12 stereomicroscopes. The best preserved were thin-sectioned in the standard transverse, tangential longitudinal and radial longitudinal sections, and studied using transmitted light under either an Olympus BX-51 or SZX12 
microscope. Images were made with Olympus Camedia 3030 and 5050 digital cameras and processed with imaging software AnalySIS, NISElements and Quick Photo Industrial. The data were analysed with Microsoft Excel 2007-2010.

\section{RESULTS}

The specimens from the Krkonoše Piedmont and Intra Sudetic Basins are characterised only by the structure of the secondary xylem. A few specimens have knots with stubs of branches. The wood is homoxylous pycnoxylic. Resin canals and axial parenchyma have not been observed. Radial sections rarely show alternate „araucaroid“ pitting in tracheid walls. Due to a considerable amount of recrystallisation, other features can only very rarely (e.g. cross-field pitting) be seen. Samples from both basins underwent the same process of recrystallisation, but samples from the Krkonoše Piedmont Basin in much less intensive way than coeval ones from the Intra Sudetic Basin (Mencl, 2007, Mencl et al., 2009).

The specimens from the Kladno-Rakovník and Pilsen Basins show better preservation being less recrystallised. However, they also have preserved the secondary xylem only. Radial sections show alternate „araucaroid“ pitting. Knots and pith are rare.

\subsection{Agathoxylon sp. 1}

Specimens: BA1, C1, P1760, P1786, P1793, P1831, P2697, S4, SH1, VS10, VS11, VS12, VS13, VS14, VS21, VS22, VS28, VS29, VS34, VS35, FP00066, FP00068, FP00069, FP00083, FP00098, FP00107, FP00112, FP00125, FP00126, FP00129, RAK004/ 1, RAK004/2, RAK004/3, RAK005/1, RAK005/2, RAK006/1, RAK008/1, RAK008/2, VS100, VS101, ZAJ002/1.

Microscopic description:

Transverse section: Growth rings not observed. Tracheids, radial diameter $20-162 \mu \mathrm{m}$ (mean $60 \mu \mathrm{m}$ ), tangential diameter $23-149 \mu \mathrm{m}$ (mean $65 \mu \mathrm{m}$ ) (Table 1), are mostly round to oval, organized in radial lines (Plate $\mathrm{I} / 2$ ). Axial parenchyma is not present.

Tangential longitudinal section: Tracheid pits not detected. Rays range from 2 to 45 cells in hight (Table 1), mostly uniseriate, partly biseriate, rarely triseriate. Rays cells are mostly round (Plate I/5).

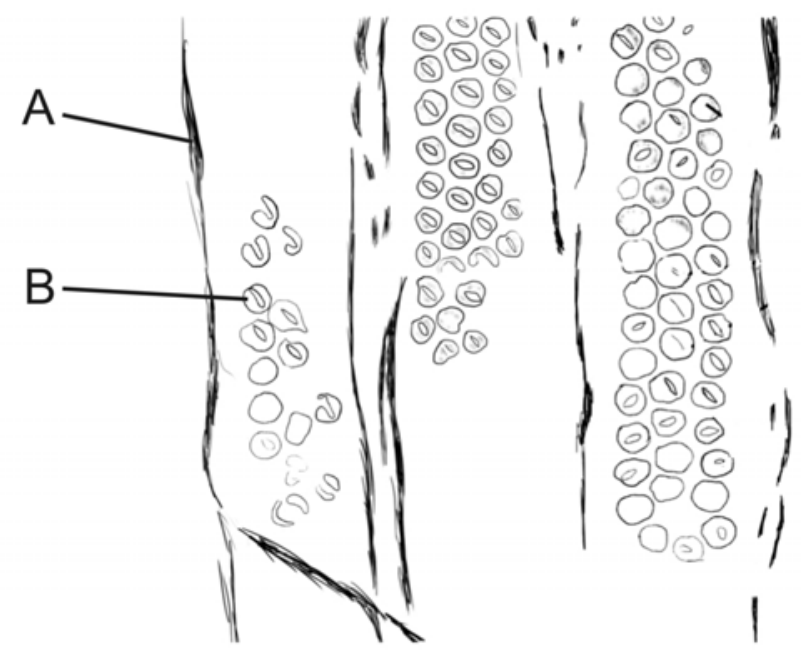

A - Tracheid wall

B - Pit with porus

Figure 3. Sketch of the radial longitudinal section of the specimen RAK004/1 - Agathoxylon sp. 1 (after Holeček, 2011).

Radial longitudinal section: Tracheid pitting $1-$ 4 columns usually covering the entire width of the tracheid wall and arranged in an alternating (,araucarioid“) pattern for maximum number of pits/cell (Plate I/6). Pits are bordered, mostly hexagonal, polygonal or oval; pores are oval or round (Figure 3). Pit diameter varies from 6 to $37 \mu \mathrm{m}$ (Table 1). Cross-field pitting is araucarioid sensu IAWA Committee (2004) and only rarely observed. Cross-field pits are bordered, hexagonal to oval, with round to oval pores, and usually three or four in each field (Plate $\mathrm{I} / 4$ ).

Macroscopic description:

Several specimens show macroscopic features: irregular branching (solitary branches without other branches in close proximity), and an Artisiatype of pith (Plate I/7). These features allow them to be identified as Agathoxylon sp. 1. Thin sectioning of these specimens was not allowed by the keepers of the Nová Paka and Krkonoše Museums, and the private collectors.

\subsection{Agathoxylon sp. 2}

Specimens: HB1, J8766, J8767, JA1, P302, P1478, P1798, P2960, P5113, PE1, S1, S3, S5, S6, S7, FP00067, FP00071, FP00073, FP00077, FP00093, FP00095, FP00100, FP00101, FP00103, FP00106, FP00115, FP00116, FP00118, FP00127, RAK003/2, ZAJ003/1, ZAS001/2, ZAS002/1, ZAS003/1. 
Table 1. Attributes of anatomical features of studied specimens with their stratigraphical positions, and their assumed systematical affiliation. Stratigraphy: I = upper Moscovian, II = Kasimovian, III = lower Gzhelian, IV = upper Gzhelian, V = Sakmarian; 1 = Kladno-Rakovník and Pilsen basins, $2=$ Krkonoše Piedmont Basin, $3=$ Intra Sudetic Basin. $\mathrm{x}=$ attributes not detectable.

\begin{tabular}{|c|c|c|c|c|c|c|c|c|c|c|c|c|c|c|c|c|c|c|}
\hline \multirow{4}{*}{\begin{tabular}{|c|} 
SECTION \\
FEATURE \\
SPECIMEN
\end{tabular}} & \multicolumn{6}{|c|}{ TRANSVERSAL } & \multicolumn{6}{|c|}{ LONGITUDINAL RADIAL } & \multirow{2}{*}{\multicolumn{4}{|c|}{$\begin{array}{c}\text { LONGITU. TANGENTIAL } \\
\text { RAYS }\end{array}$}} & \multirow{4}{*}{$\begin{array}{c}\text { STRATIGRA } \\
\text { PHIC } \\
\text { POSITION }\end{array}$} & \multirow{4}{*}{$\begin{array}{c}\text { Agatho- } \\
\text { xylon } \\
\text { sp. }\end{array}$} \\
\hline & \multicolumn{6}{|c|}{ TRACHEID DIAMETER } & \multicolumn{6}{|c|}{ PITTING } & & & & & & \\
\hline & radis & l direc & tion & tange & tial dir & ection & & series & & & diame & & & height & & series & & \\
\hline & $\min$ & $\max$ & mean & $\min$ & $\max$ & mean & $\min$ & $\max$ & mean & $\min$ & $\max$ & mean & $\min$ & $\max$ & mean & $\max$ & & \\
\hline \begin{tabular}{l|l}
$\mathrm{BA} 1$ & \\
\end{tabular} & 49 & 142 & 80,5 & 44 & 129 & 87 & 3 & 5 & 4 & 11 & 25 & 17,9 & $\mathrm{x}$ & $\mathrm{x}$ & $\mathrm{x}$ & $\mathrm{x}$ & $\mathrm{IV} / 2$ & 1 \\
\hline HB1 & 72 & 121 & 92,3 & 54 & 148 & 84,3 & 1 & 1 & 1 & 9 & 31 & 16 & $x$ & $x$ & $x$ & $x$ & $\mathrm{~V} / 1$ & 2 \\
\hline JA1 & 36 & 60 & 45 & 34 & 55 & 43 & $x$ & $x$ & $x$ & $x$ & $\mathrm{x}$ & $x$ & 4 & 26 & 14 & 2 & $\mathrm{II} / 2$ & 2 \\
\hline $\mathrm{P} 1760$ & 34 & 84 & 57,4 & 47 & 90 & 62,1 & 2 & 3 & 2 & 8 & 16 & 11,5 & $x$ & $\mathrm{x}$ & $x$ & $x$ & $\mathrm{II} / 2$ & 1 \\
\hline P2697 & 45 & 162 & 97,4 & 34 & 149 & 98,2 & 2 & 4 & 4 & 6 & 12 & 8 & 10 & 23 & 19 & 2 & $\mathrm{IV} / 2$ & 1 \\
\hline P2960 & $x$ & $\mathrm{x}$ & $\mathrm{x}$ & $x$ & $\mathrm{x}$ & $\mathrm{x}$ & 1 & 1 & 1 & 10 & 14 & 11,6 & $x$ & $x$ & $x$ & $x$ & $\mathrm{~V} / 1$ & 2 \\
\hline PE1 & $x$ & $x$ & $x$ & $x$ & $x$ & $x$ & 1 & 1 & 1 & 8 & 14 & 10 & $x$ & $x$ & $x$ & $x$ & $\mathrm{II} / 2$ & 2 \\
\hline $\mathrm{S} 1$ & $x$ & $x$ & $x$ & $x$ & $x$ & $\mathrm{x}$ & 1 & 1 & 1 & 11 & 25 & 16,7 & 5 & 22 & 8 & 2 & $\mathrm{~V} / 1$ & 2 \\
\hline S3 & 18 & 41 & 26,8 & 21 & 40 & 29,9 & 1 & 1 & 1 & 8 & 12 & 10 & 4 & 14 & 9 & 2 & $\mathrm{~V} / 1$ & 2 \\
\hline $\mathrm{S} 4$ & $x$ & $x$ & $x$ & $x$ & $x$ & $x$ & 1 & 2 & 1,2 & 9 & 15 & 12,8 & $x$ & $x$ & $x$ & $x$ & $\mathrm{~V} / 1$ & 1 \\
\hline S5 & $x$ & $x$ & $x$ & $x$ & $x$ & $x$ & 1 & 1 & 1 & 6 & 12 & 8,3 & 5 & 20 & 11 & 2 & $\mathrm{~V} / 1$ & 2 \\
\hline S6 & $x$ & $x$ & $x$ & $x$ & $x$ & $x$ & 1 & 2 & 1,1 & 12 & 20 & 16,3 & $x$ & $x$ & $x$ & $x$ & $\mathrm{~V} / 1$ & 2 \\
\hline S7 & 33 & 73 & 49 & 38 & 109 & 72,7 & 1 & 1 & 1 & 8 & 34 & 23 & $x$ & $x$ & $x$ & $x$ & $\mathrm{~V} / 1$ & 2 \\
\hline SH1 & 20 & 58 & 38,8 & 27 & 52 & 37,3 & 2 & 2 & 2 & 16 & 37 & 21,8 & $x$ & $x$ & $x$ & $x$ & $\mathrm{I} / 2$ & 1 \\
\hline VS10 & 60 & 90 & 70 & 60 & 100 & 72,5 & 2 & 3 & 2 & 18 & 25 & 23 & 5 & 21 & 16 & 3 & $\mathrm{II} / 3$ & 1 \\
\hline VS11 & 60 & 100 & 71 & 70 & 110 & 78,5 & $x$ & $x$ & $x$ & $\mathrm{x}$ & $x$ & $x$ & 2 & 9 & 6 & 2 & $\mathrm{II} / 3$ & 1 \\
\hline VS12 & $x$ & $x$ & $x$ & $x$ & $x$ & $\mathrm{x}$ & 3 & 4 & 3,8 & 7 & 13 & 9,6 & 8 & 23 & 19 & 2 & $\mathrm{II} / 3$ & 1 \\
\hline VS13 & $x$ & $x$ & $\mathrm{x}$ & $\mathrm{x}$ & $x$ & $x$ & 2 & 3 & 2,2 & 10 & 20 & 15 & 7 & 16 & 10 & 2 & $\mathrm{II} / 3$ & 1 \\
\hline VS14 & 50 & 80 & 64,5 & 55 & 80 & 66 & $x$ & $x$ & $x$ & $\mathrm{x}$ & $x$ & $\mathrm{x}$ & 4 & 28 & 10 & 2 & $\mathrm{II} / 3$ & 1 \\
\hline VS21 & 40 & 60 & 54,5 & 40 & 75 & 61,5 & $x$ & $x$ & $x$ & $x$ & $x$ & $x$ & $x$ & $x$ & $x$ & $x$ & $\mathrm{II} / 3$ & 1 \\
\hline VS22 & 40 & 70 & 55,5 & 50 & 80 & 65 & $x$ & $x$ & $x$ & $x$ & $x$ & $x$ & 3 & 11 & 7 & 2 & $\mathrm{II} / 3$ & 1 \\
\hline VS28 & 60 & 90 & 71 & 60 & 100 & 78 & $x$ & $x$ & $x$ & $x$ & $x$ & $x$ & $x$ & $x$ & $x$ & $x$ & $\mathrm{II} / 3$ & 1 \\
\hline VS29 & 60 & 100 & 78,5 & 60 & 100 & 85 & $x$ & $x$ & $x$ & $x$ & $x$ & $x$ & 4 & 16 & 8 & 2 & $\mathrm{II} / 3$ & 1 \\
\hline VS34 & 40 & 70 & 52 & 50 & 90 & 75 & 2 & 3 & 2,3 & 12 & 21 & 17 & 6 & 30 & 13 & 2 & $\mathrm{II} / 3$ & 1 \\
\hline VS35 & 40 & 70 & 51,5 & 40 & 80 & 58,5 & 1 & 3 & 2,5 & 11 & 25 & 14 & 3 & 18 & 8 & 1 & $\mathrm{II} / 3$ & 1 \\
\hline P5113 & 13 & 30 & 21,2 & 16 & 38 & 27,3 & 1 & 2 & 1,2 & 11 & 16 & 13,3 & $x$ & $\mathrm{x}$ & $x$ & $x$ & IV $/ 1$ & 2 \\
\hline FP00071 & 45 & 50 & 47,5 & $x$ & $x$ & $\mathrm{x}$ & 1 & 2 & 1,1 & 18 & 18 & 18 & 6 & 6 & 6 & 1 & IV/1 & 2 \\
\hline FP00073 & 30 & 35 & 32,5 & $x$ & $x$ & $x$ & 1 & 1 & 1 & 12 & 15 & 13 & $x$ & $x$ & $x$ & $x$ & IV/1 & 2 \\
\hline FP00077 & 40 & 50 & 44,7 & $x$ & $x$ & $x$ & 1 & 1 & 1 & 15 & 20 & 18 & 6 & 14 & 9 & 1 & IV/1 & 2 \\
\hline FP00083 & 70 & 80 & 73,3 & $x$ & $x$ & $x$ & 2 & 4 & 3,1 & 10 & 12 & 11 & 7 & 7 & 7 & 1 & $\mathrm{IV} / 1$ & 1 \\
\hline FP00093 & 45 & 50 & 46,7 & $x$ & $x$ & $x$ & 1 & 2 & 1,1 & 12 & 15 & 13 & $x$ & $x$ & $x$ & $x$ & IV/1 & 2 \\
\hline FP00095 & 40 & 50 & 46,7 & $x$ & $x$ & $x$ & 1 & 1 & 1 & 17 & 18 & 17,3 & 16 & 16 & 16 & 1 & $\mathrm{IV} / 1$ & 2 \\
\hline FP00098 & 55 & 65 & 60 & $x$ & $x$ & $x$ & 1 & 2 & 1,7 & 12 & 12 & 12 & 6 & 29 & 18 & 1 & IV/1 & 1 \\
\hline FP00100 & 40 & 40 & 40 & $x$ & $x$ & $x$ & 1 & 2 & 1,1 & 15 & 15 & 15 & $x$ & $x$ & $x$ & $x$ & $\mathrm{IV} / 1$ & 2 \\
\hline FP00101 & 40 & 50 & 46,7 & $x$ & $x$ & $x$ & 2 & 4 & 2,9 & 15 & 15 & 15 & 4 & 5 & 5 & 1 & IV/1 & 2 \\
\hline FP00103 & 30 & 40 & 33,3 & $x$ & $x$ & $x$ & 1 & 2 & 1,8 & 10 & 15 & 13 & $x$ & $x$ & $x$ & $x$ & IV/1 & 2 \\
\hline FP00106 & 40 & 50 & 45 & $x$ & $x$ & $x$ & 1 & 2 & 1 & 15 & 15 & 15 & $x$ & $x$ & $x$ & $x$ & $\mathrm{IV} / 1$ & 2 \\
\hline FP00107 & 50 & 50 & 50 & $x$ & $x$ & $x$ & 1 & 1 & 1 & 18 & 18 & 18 & 7 & 10 & 9 & 1 & IV/1 & 1 \\
\hline FP00112 & 40 & 50 & 45 & $x$ & $x$ & $x$ & 1 & 2 & 1,7 & 12 & 12 & 12 & $x$ & $x$ & $x$ & $x$ & IV/1 & 1 \\
\hline FP00115 & 50 & 60 & 55 & $x$ & $x$ & $x$ & 1 & 3 & 1,8 & 15 & 15 & 15 & 7 & 9 & 8 & 1 & IV/1 & 2 \\
\hline FP00116 & 50 & 50 & 50 & $x$ & $x$ & $x$ & 1 & 3 & 2 & 15 & 15 & 15 & 15 & 25 & 20 & 1 & $\mathrm{IV} / 1$ & 2 \\
\hline FP00118 & 40 & 40 & 40 & $x$ & $x$ & $x$ & 1 & 1 & 1 & 15 & 18 & 17 & 7 & 7 & 7 & 1 & IV/1 & 2 \\
\hline FP00125 & 50 & 50 & 50 & $x$ & $x$ & $x$ & 2 & 3 & 2,4 & 10 & 10 & 10 & $x$ & $x$ & $x$ & $x$ & IV/1 & 1 \\
\hline FP00126 & 45 & 50 & 48,3 & $x$ & $x$ & $x$ & 2 & 4 & 2,4 & 10 & 10 & 10 & 7 & 12 & 9 & 1 & $\mathrm{IV} / 1$ & 1 \\
\hline FP00127 & 40 & 50 & 43,3 & $x$ & $x$ & $x$ & 1 & 1 & 1 & 12 & 12 & 12 & $x$ & $x$ & $x$ & $x$ & IV/1 & 2 \\
\hline FP00129 & 50 & 50 & 50 & $x$ & $x$ & $\mathrm{x}$ & 1 & 3 & 2 & 12 & 12 & 12 & 9 & 12 & 10 & 1 & $\mathrm{IV} / 1$ & 1 \\
\hline RAK003/2 & 42 & 65 & 51,3 & 34 & 69 & 50,8 & 2 & 2 & 2 & 14 & 16 & 15,6 & $x$ & $\mathrm{x}$ & $x$ & $x$ & III/1 & 2 \\
\hline RAK004/1 & 36 & 85 & 59,7 & 40 & 75 & 56,5 & 1 & 4 & 3 & 10 & 12 & 10,9 & 2 & 23 & 9 & 2 & $\mathrm{II} / 1$ & 1 \\
\hline RAK004/2 & 32 & 61 & 48,7 & 30 & 59 & 44,4 & 1 & 3 & 2 & 10 & 13 & 11,4 & 2 & 30 & 9 & 3 & $\mathrm{II} / 1$ & 1 \\
\hline RAK004/3 & 28 & 61 & 42,9 & 23 & 52 & 39 & 1 & 3 & 2 & 10 & 13 & 12 & 3 & 22 & 7 & 2 & $\mathrm{II} / 1$ & 1 \\
\hline RAK005/1 & 41 & 79 & 63,6 & 39 & 71 & 54,1 & 1 & 3 & 3 & 15 & 16 & 15,7 & 2 & 35 & 11 & 2 & $\mathrm{II} / 1$ & 1 \\
\hline RAK005/2 & 56 & 79 & 65,6 & 52 & 87 & 72,2 & 2 & 4 & 3 & 13 & 16 & 14 & 3 & 45 & 13 & 2 & $\mathrm{II} / 1$ & 1 \\
\hline RAK006/1 & 40 & 72 & 53,8 & 38 & 80 & 59,1 & 1 & 2 & 2 & 12 & 17 & 14 & 3 & 22 & 11 & 2 & $\mathrm{II} / 1$ & 1 \\
\hline RAK008/1 & 51 & 90 & 66,2 & 40 & 67 & 55,4 & 2 & 3 & 2 & 10 & 15 & 13,4 & 3 & 27 & 14 & 3 & $\mathrm{II} / 1$ & 1 \\
\hline RAK008/2 & 30 & 61 & 47,1 & 32 & 71 & 49,3 & 1 & 2 & 1 & 13 & 14 & 13,7 & 2 & 30 & 14 & 1 & $\mathrm{II} / 1$ & 1 \\
\hline ZAJ002/1 & $x$ & $\mathrm{x}$ & $\mathrm{x}$ & $x$ & $x$ & $\mathrm{x}$ & $x$ & $x$ & $x$ & $x$ & $x$ & $\mathrm{x}$ & 4 & 26 & 12 & 2 & IV/1 & 1 \\
\hline ZAJ003/1 & $x$ & $x$ & $x$ & $x$ & $x$ & $x$ & 1 & 2 & 1 & 15 & 23 & 19 & 2 & 26 & 9 & 2 & $\mathrm{IV} / 1$ & 2 \\
\hline ZAS001/2 & $x$ & $x$ & $x$ & $x$ & $x$ & $x$ & 1 & 2 & 1 & 12 & 20 & 15,7 & $x$ & $x$ & $x$ & $x$ & IV/1 & 2 \\
\hline ZAS002/1 & $x$ & $x$ & $x$ & $x$ & $x$ & $x$ & 1 & 2 & 1 & 11 & 14 & 13,4 & $x$ & $x$ & $x$ & 1 & IV/1 & 2 \\
\hline ZAS003/1 & $x$ & $x$ & $x$ & $x$ & $x$ & $x$ & 1 & 2 & 1 & 9 & 14 & 11,1 & $x$ & $x$ & $x$ & $x$ & IV/1 & 2 \\
\hline
\end{tabular}




\section{Plate I.}
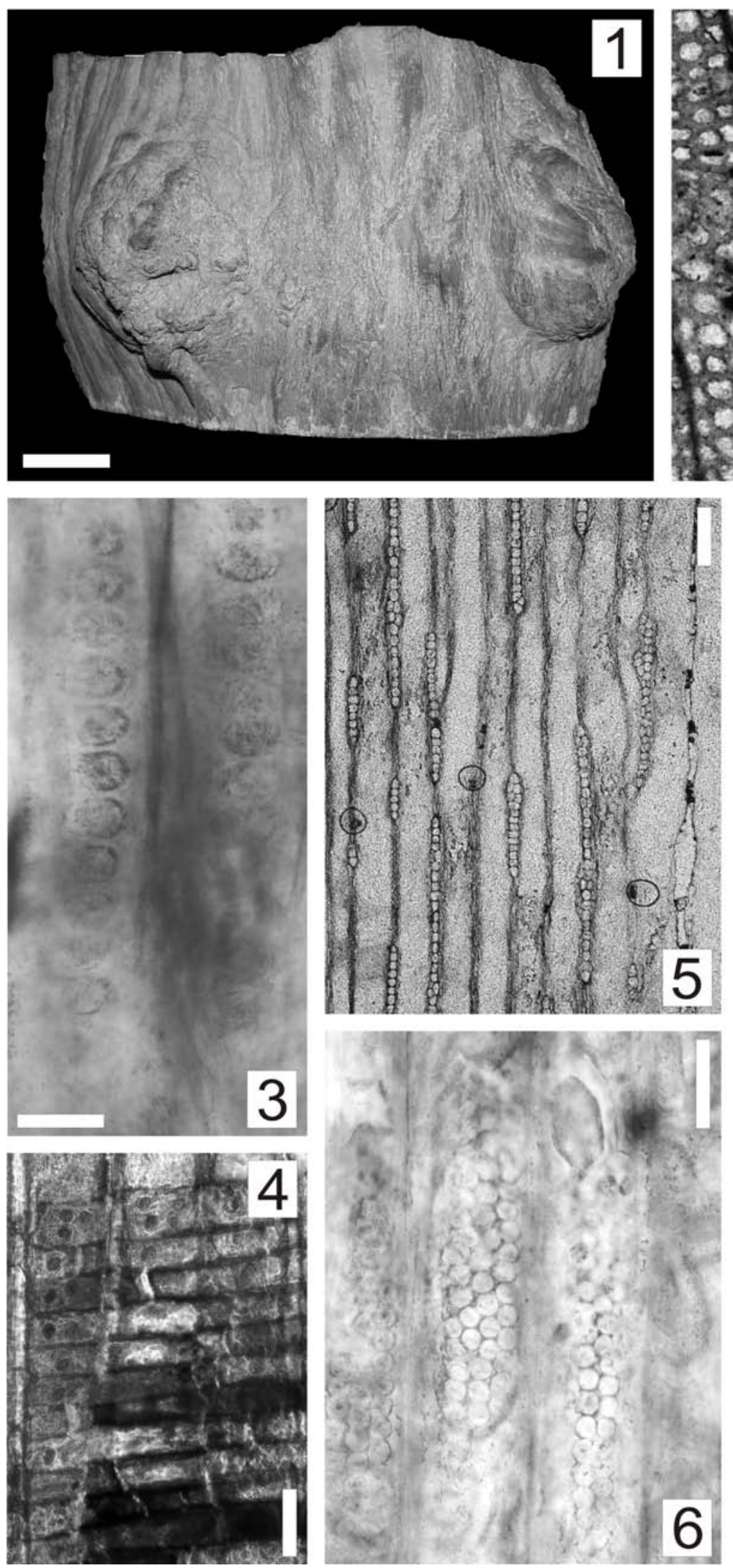
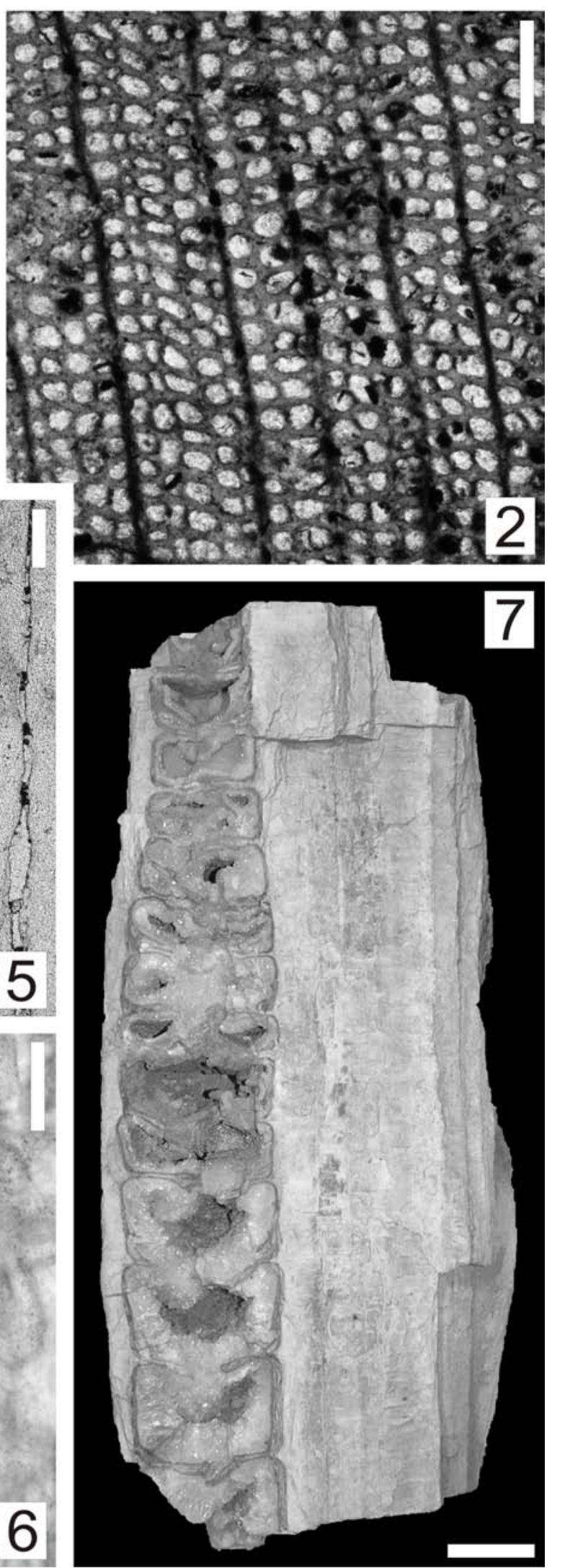
Microscopic description:

Transverse section: Growth rings were not observed. Tracheids are round or oval, rarely irregular, arranged in radial lines, radial diameter 13 $121 \mu \mathrm{m}$ (mean $44 \mu \mathrm{m}$ ), tangential diameter 16 $148 \mu \mathrm{m}$ (mean $51 \mu \mathrm{m}$ ) (Table 1). Axial parenchyma was not observed.

Tangential longitudinal section: Tracheid pits were not detected. Rays are uni- to biseriate, $2-26$ cells in height (Table 1). Ray cells are round to slightly oval.

Radial longitudinal section: Tracheid pitting is mostly uniseriate, locally biseriate. Pits are bordered, round, diameters $6-37 \mu \mathrm{m}$ (Table 1), and do not cover the total width of a tracheid wall (Table 1). Pores are round or slightly oval. Cross-field pitting not observed.

Macroscopic description:

Some of specimens of group Agathoxylon sp. 2 have preserved knots with the bases of branches. Branching pseudo-verticillate; with the branches arranged round the stem in the same orthogonal plane (Plate I/1).

\section{DISCUSSION}

\subsection{Taxonomy}

Only the characters of the secondary xylem are known for all specimens studied, the primary xylem and other tissues are lacking. Wood is homoxylous pycnoxylic without resin canals and axial parenchyma. Regular growth rings were not observed. Based on the known general characters (alternate pitting, lack of axial parenchyma) is possible to classify all the wood from the four basins as Agathoxylon sp. (Rößler et al., in press). However, due to strong recrystallisation of the quartz and the effect that has on the details visible in the wood it is not possible to make a more pre- cise determination. Two groups (Agathoxylon sp. 1 and Agathoxylon sp. 2) are recognized based on the nature of the pitting in radial walls of the tracheids. All other features of the secondary xylem were either not discernable due to recrystallisation of the quartz or only hardly visible because of the poor preservation.

There is however a few well-preserved macroscopic features that permit the assignment, with reservations, of the two groups of Agathoxylon to higher levels of classification. Agathoxylon sp. 1 is probably assignable to the cordaitaleans, and Agathoxylon sp. 2 can possibly be assigned to the conifers (sensu Doubinger and Marguerier, 1975 and Noll et al., 2005).

\subsection{Summary of stratigraphic and geographic occurrence}

Using available palaeobotanical data and the occurrence of silicified stems we are able to partially reconstruct floral assemblages at various stratigraphic levels in the four studied basins.

\subsubsection{Upper Moscovian (Asturian)}

The Nýřany Member of the Kladno Formation (Kladno-Rakovník and Pilsen Basins) and the Brusnice Member of the Kumburk Formation (Krkonoše Piedmont Basin) were deposited during this time interval. Silicified stems of this age are not known from the Intra Sudetic Basin. Specimens from the Kladno-Rakovník and Pilsen Basins were collected in the Lišany and Lužná as loose pieces in fields (Holeček, 2011). Unfortunately, their preservation is very poor and any further classification of them is not possible. Two specimens are known from the Krkonoše Piedmont Basin near Šárovcova Lhota. Both of them were collected from outcrops and have been classified as cordaitalean wood (see Table 1).

\section{Plate I.}

1. Part of a stem with pseudo-verticillate branching (specimen J8766, Krkonoše Piedmont Basin). Scale bar = 30 mm; 2. General view of tracheids of secondary xylem, transversal section (specimen P2697, Krkonoše Piedmont Basin). Scale bar $=1 \mathrm{~mm}$; 3. Detail of tracheid pitting of Agathoxylon sp. 2, radial longitudinal section (specimen S1, Krkonoše Piedmont Basin). Scale bar $=30 \mu \mathrm{m} ; 4$. Detail of cross-field pitting of Agathoxylon sp. 1, radial longitudinal section (specimen RAK006/1, Kladno-Rakovník Basin). Scale bar $=50 \mu \mathrm{m} ; 5$. Detail of tangential longitudinal section showing mostly uniseriate but locally biseriate rays (specimen RAK005/2, Kladno-Rakovník Basin). Scale bar $=0.1 \mathrm{~mm}$; 6. Detail of tracheid pitting of Agathoxylon sp. 1, radial longitudinal section; note crowded hexagonal pits (specimen FP00098, Pilsen Basin). Scale bar = 50 $\mu$ m; 7. General view of the unique specimen with preserved pith of Artisia-type (specimen C1, Kladno-Rakovník Basin). Scale bar $=20 \mathrm{~mm}$. 


\subsubsection{Kasimovian (Stephanian A)}

Silicified stems of this age are very common and are known from all four studied basins. Most of the specimens from the Kladno-Rakovník and Pilsen Basins (Týnec Formation) are cordaitaleans (Holeček, 2011). Specimens from the Krkonoše Piedmont Basin (Štikov Arkoses, Kumburk Formation) are mostly conifers. From the Intra Sudetic Basin (Žaltman Arkoses, Odolov Formation) seven, well preserved specimen can be assigned to the cordaitaleans (Mencl, 2007, Mencl et al., 2009).

\subsubsection{Upper Kasimovian (Stephanian B)}

Specimens of this age are known only from the Kladno-Rakovník Basin. The only identifiable specimen is possibly cordaitalean (Holeček, 2011).

\subsubsection{Lower Gzhelian (Stephanian C)}

The Kladno-Rakovník, Pilsen and Krkonoše Piedmont Basins have a rich stem flora of this age, while lacking in the Intra Sudetic Basin. The Líně Formation, localities of Zbůch, Tlučná and Chotíkov, stems are $2 / 3$ conifers and $1 / 3$ cordaitaleans (Bureš, 2011). In the Krkonoše Piedmont Basin, the Ploužnice Horizon (Semily Formation) is well known for occurrence of several types of silicified stems, e.g., calamitaleans, ferns, pteridosperms and gymnosperms (Matysová, 2006; Matysová et al., 2008; Matysová et al., 2010; Mencl et al., 2013). All studied specimens from the Balka and Lísek localities are cordaitaleans.

\subsubsection{Asselian - Sakmarian (Autunian)}

Specimens from the Krkonoše Piedmont Basin are the only ones know from this age, with most probably assignable to the conifers.

\section{CONCLUSIONS}

During our research we studied several dozen of silicified Agathoxylon-type of stems from the KladnoRakovník, Pilsen, Krkonoše Piedmont and Intra Sudetic late Paleozoic basins. Based on previous studies and new field research, silicified stems are now known to be present at five stratigraphic levels. All of them are always decorticated with secondary xylem only. They are rarely preserved in outcrops, but never in upright position. More often are found in alluvial deposits or as loose pieces in fields. Because of lack of outcrops, the assigning of these specimens to their stratigraphic positions can be done according to a detailed field- work in combination with the previous geological mapping data. The preservation of anatomical features is generally poor due to high recrystallisation of the quartz and destruction of the organic matter. The best preserved specimens are from the Kladno-Rakovník and Pilsen Basins, and the most poorly preserved from the Intra Sudetic Basin. Our studies of the secondary xylem resulted in the assignment of the specimens into two groups, Agathoxylon sp. 1 and Agathoxylon sp. 2. Agathoxylon sp. 1 exhibits features indicative of the cordaitaleans, while the homologous features in Agathoxylon sp. 2 are indicative of the conifers. The most significant contribution to the understanding of the floras of this time is that the cordaitaleans - conifer ratio in Western Bohemia basins is obviously different that in the Krkonoše Piedmont Basin. This fact is probably a reflection of differing palaeoenvironments.

\section{ACKNOWLEDGEMENTS}

We would like to thank J. Luštinec and other employees of the Krkonoše Museum in Jilemnice, J. Simurda (Krkonoše Museum in Vrchlabí) and T. Řídkošil (Czech Paradise Museum Turnov) as well as private collectors J. Červenka, J. Svejkovský, J. Zajíček and B. Zasadil for kind provide samples of their collections. Many thanks to V. Prouza (Czech Geological Survey) and J. Holeček (Radioactive Waste Repository) for their help with field works and fruitful discussion, and F. Tichávek for thin-sectioning. The manuscript was improved by the thorough reviews of S. Opluštil and Z. Kvaček, and detailed linguistic and scientific correction by D. Chaney. The research was supported by the project MSM0021620855, PRVOUK P44, SVV261203, UU09/2011 and FRL 2013.

\section{REFERENCES}

Březinová, D. 1970. Přehled dosavadních nálezů fosilních dřev na území Československa zpracovaných na základě literárních pramenů. Manuscript, National Museum, Prague.

Bureš, J. 2011. Silicified cordaite and conifers wood in the sediments of the Líně Formation of the Pilsen Carboniferous Basin. Erica 18, 179 198. Plzeň (in Czech).

Bureš, J. 2013. Morphological-anatomical research of two large trunks of pycnoxylic woods (cordaitalean plants) from the Stephanian of Pilsen basin. Erica 20, 179 - 190. Plzeň (in Czech). 
Daněk, J. J. 1902. Studie o permském útvaru v Čechách. Archiv pro př́r. prozk. Čech XI (6).

Dernbach, U. 1996. The Petrified Forest of Nová Paka. In Dernbach, U. (ed.) Petrified Forests, 116 - 117. D'ORO Publishers, Heppenheim.

Dernbach, U., Tidwell, D. W., Barthel, M., Galtier, J., Jung, W., Kerp, H., Noll, R., Rößler, R., Rothwell, W. G., Selmeier, A., Stockey, A. R., Wilde, V., Wright, W. W. 2002. Secrets of Petrified Plants, Fascination from Millions of Years. 232 pp. D’ORO Publishers, Heppenheim.

Doubinger, J., Marguerier, J. (1975). Paléoxylologie: Étude anatomique comparée de Scleromedulloxylon aveyronense nov. gen. nov. sp. du Permien de St-Affrique (Aveyron, France); considérations taxinomiques et stratigraphiques. Géobios 8, 25 - 59.

Dvořák, Z., Švancara, M., 2003. Naleziště zkamenělých stromů u Slaného. Minerál 11, 403 406.

Feistmantel, K. 1883. Über Araucarioxylon in der Steinkohlenablagerung von Mittel-Böhmen. Abh. d. k. b. Ges. d. Wiss. 6 (12), 1 - 24.

Feistmantel, O. 1873a. O zkřemenělých kmenech v permském útvaru českém. Vesmír 2, 176 178, 190 - 192, 208. Praha.

Feistmantel, O. 1873b. Über die Verbreitung und geologische Stellung der verkieselten Araucariten - Stämme in Böhmen. Sitzungsberichte d. $k$. b. Ges. d. Wiss. 5, $204-220$.

Feistmantel, O. 1873c. Geologische Stellung und Verbreitung der Verkieselten Hölzer in Böhmen. Verhandlung der k.k. geologische Reichsanstalt. 168 (6), 108 - 112.

Frič, A. 1912. Studie v oboru českého útvaru permského. Arch. př́rodov. prozk. země čes. 15. Praha.

Goeppert, H. R. 1857. Über den versteinerten Wald von Radowenz bei Adersbach in Böhmen und über den Versteinungsprocess überhaupt. Jahrbuch k. k. geologische Reichanstalt 8, 725 - 738.

Goeppert, H. R. 1858. Ueber die versteinerten Wälder im nördlichen Böhmen und in Schlesien. Jahresber. d. Schles. Ges. für vaterländ. Cultur $36,41-49$.

Gradstein, F. M., Ogg, J. G., Schmitz, M. D., Ogg, G. M. 2012. The Geologic Time Scale, 603 - 679. Elsevier, Amsterdam.

Havlena, V. 1955. Vývoj stratigrafie permokarbonských uhelných oblastí Čech a Moravy. Knihovna ÚÚG 28. Praha.
Havlena, V. 1958. Studie o geologii a stratigrafii permokarbonského synklinoria v Podkrkonoší. Rozpravy Čsl. akademie věd, řada MPV 68 (7). Praha.

Havlena, V. 1964. Geologie uhelných ložisek 2. ČSAV Praha. 440 pp.

Heber, F. A. 1844. Böhmens Burgen, Vesten und Bergschlösser 2. C. M. Medau Praha.

Holeček, J. 2011. Late Carboniferous silicified wood from the western part of the Kladno-Rakovník Basin. 135 pp. Master thesis, Charles University, Prague (in Czech).

Hynie, O. 1927. Dosavadní výsledky mého mapování v permu podkrkonošském. Věstník Stát. geol. ústavu Čsl. republiky III (6). Praha.

IAWA Committee 2004. IAWA list of microscopic features for softwood identification. IAWA J, 25, $1-70$.

Jokély, J. 1861. Bemerkungen über die Verbreiterung der Araucaritenstämme. Jahrbuch d. geol. Reichsanstalt 2, 392 - 395.

Katzer, F. 1892. Geologie von Böhmen. 1606 pp. Praha.

Makowsky, A. (1878): Der „versteinerte Wald“ bei Radowenz in Böhmen. Verhandlungen des naturforschenden Vereines in Brünn, 17, 57-64.

Matysová, P. 2006. Permocarboniferous silicified woods from the Intra Sudetic and Krkonoše Piedmont Basins: taxonomy and instrumental analysis. 195 pp. Master thesis, Charles University, Prague (in Czech).

Matysová, P., Leichmann, J., Grygar, T., Rössler, R., 2008. Cathodoluminescence of silicified trunks from the Permo-Carboniferous basins in eastern Bohemia, Czech Republic. European Journal of Mineralogy 20, 217 - 231.

Matysová, P., Rössler, R., Götze, J., Leichmann, J., Forbes, G., Taylor, E. L., Sakala, J., Grygar, T. 2010. Alluvial and volcanic pathways to silicified plant stems (Upper Carboniferous-Triassic) and their taphonomic and palaeoenvironmental meaning. Palaeogeogr. Palaeoecl. 292, 127 - 143.

Mencl, V. 2007. Upper Carboniferous silicified wood of the Intra Sudetic Basin: systematics and palaeoenvironment. 105 pp. Master thesis, Charles University, Prague (in Czech).

Mencl, V., Matysová, P., Sakala, J. 2009. Silicified wood from the Czech part of the Intra Sudetic Basin (Late Pennsylvanian, Bohemian Massif, Czech Republic): systematics, silicification and palaeoenvironment. N. Jb. Geol. Paläont. Abh. 252,269 - 288. 
Mencl, V., Holeček, J., Roessler, R., Sakala, J. 2013. First anatomical description of silicified calamitalean stems from the upper Carboniferous of the Bohemian Massif (Nová Paka and Rakovník areas, Czech Republic). Rev. Palaeobot. Palynol. 197, 70 - 77.

Miksch, J. 1853: Vorkommen fossile Hölzer bei Pilsen. Korrespondenzblatt des zool.-miner. Vereins in Regensburg, 7 - 14.

Mikuláš, R., Zasadil, B. 2008. Paleontologický význam dutin ve fosilních dřevech permokarbonského stáří středočeských a západočeských kamenouhelných pánví. Zprávy o geologických výzkumech $v$ roce 2007, 124 - 127.

Němejc, F. 1953. Úvod do floristické stratigrafie kamenouhelných oblastí v ČSR. 173 pp. ČSAV, Praha.

Noll, R., Rössler, R., Wilde, V. 2005. 150 Jahre Dadoxylon - Zur Anatomie fossiler Koniferenund Cordaitenhölzer aus dem Rotliegend des euramerischen Florengebietes. Veröffentlichungen des Museums für Naturkunde Chemnitz 28, 29 - 48. Chemnitz.

Obrhel, J. 1977. Několik paleontologických nálezů ve svrchním karbonu kladensko-rakovnické pánve. Časopis Národního muzea 146, 41 - 42.

Opluštil, S., Cleal, C. J. 2007. A comparative analysis of some Late Carboniferous basins of Variscan Europe. Geological Magazine 144 (3), 417 - 448.

Opluštil, S., Šimůnek, Z., Zajíc, J., Mencl, V. 2013. Climatic and biotic changes around the Carboniferous/Permian boundary recorded in the continental basins of the Czech Republic. International Journal of Coal Geology 119, 114 - 151.

Pešek, J. 1968. K významu araukaritů pro stratigrafii sedimentů plzeňské pánve. Časopis pro mineralogii a geologii 13, 213.

Pešek, J., Holub, V., Jaroš, J., Malý, L., Martínek, K., Prouza, V., Spudil, J., Tásler, R. 2001. Geologie a ložiska svrchnopaleozoických limnických pánví České republiky. 244 pp. Český geologický ústav Praha.

Petrascheck, W. 1924. Kohlengeologie der österreichischen Teilstaaten, Teil I. Wien.

Pouba Z., Špinar Z. 1954: Stratigrafické poměry okolí kaolínového ložiska u Chlumčan (jižní část plzeňské pánve). Věstník ÚÚG 29, 145 158. Praha.

Purkyně, C. 1927. O nalezištích zkřemenělých kmenů araukaritových v Čechách, zvláště v Podkrkonoší. Časopis Národ. muzea 51, 113 - 131.
Řehoř, M., Řehoř, V. 2005. Pozoruhodný nález zkamenělého dřeva na lokalitě Očihov. Minerál 3/ 2005, 178 - 180 .

Renger, K. 1858. Skamenělé kmeny v Čechách. Živa VI, 254.

Renger, K. 1863. O skamenělém lese radvanickém blíže Abrspachu a o spůsobech skamenění vůbec. Živa 4, 362 - 375.

Rößler, R., Philippe, M., van Konijnenburg-van Cittert, J. H. A., McLoughlin, S., Sakala, J., Zijlstra, G. \& al. in press. Which name(s) should be used for Araucaria-like fossil wood? Results of a poll. Taxon, doi: http://dx.doi.org/ 10.12705/631.7.

Sakala, J., Mencl, V., Matysová, P. 2009. New data on Upper Carboniferous silicified stems of calamites from the Nová Paka region. Geoscience Research Reports for 2008, 111 - 113 (in Czech).

Skoček, V. 1970. Silicifikovaná dřeva ve středočeském permokarbonu. Věst. Ústř. ústavu geol. 45, 87 - 92 .

Soukup, J. 1997. Silicifikovaná dřeva v západním Podkrkonoší. Minerál 5 (3), 180 - 182.

Stárková, M., Šimůnek, Z., Martínek, K. 2009. Prepared research of Ploužnice Horizon Semily Formation; genesis and palaeoecology of lacustrine facies. Acta Musei Turnoviensis 4, $120-124$.

Stur, D. 1877: Zwei Notizen über die Araucariten in nordöstlichen Bohmen. Verhandlung der k. k. geologische Reichsanstalt, 237 - 240.

Svejkovský, J. 2009. Geologie Podbořanska. 78 pp. Sdružení MAC spol. s.r.o. Praha.

Tásler, R., Čadková, Z., Dvořák, J., Fediuk, F., Chaloupský, J., Jetel, J., Kaiserová-Kalibová, M., Prouza, V., Schovánková-Hrdličková, D., Středa, J., Stř́ida, M., Šetlík, J. 1979. Geologie české části vnitrosudetské pánve. 296 pp. ÚÚG Praha.

Valín, F. 1956. Hydrodynamické podmínky během sedimentace žaltmanských arkóz. Zprávy o geologických výzkumech v r. 1956, 182 - 183. Praha.

Valín, F. 1960. Litologie souvrství žaltmanských arkóz. Sborník ÚÚG 26, 409 - 437. Praha.

Vítek, J. 1986. Araukarity v Nové Pace. Př́rr. vědy šk. 37 (5), 175.

Vysocký, P. 1859. Některé poměry permského útvaru v severozápadních Čechách. Živa VII, $211-218$. 